\title{
Doublecortin-expressing cell types in temporal lobe epilepsy
}

\author{
Joan Y. W. Liu' ${ }^{1,2,7}$, Mar Matarin', Cheryl Reeves ${ }^{1,2}$, Andrew W. McEvoy ${ }^{1,5}$, Anna Miserocchi ${ }^{5}$, Pamela Thompson ${ }^{1,4,6}$,
} Sanjay M. Sisodiya ${ }^{1,3,6}$ and Maria Thom ${ }^{1,2^{*}}$ (i)

\begin{abstract}
Doublecortin (DCX) is widely regarded as a marker of immature and migrating neurons during development. While DCX expression persists in adults, particularly in the temporal lobe and neurogenic regions, it is unknown how seizures influence its expression. The aim of the present study was to explore the distribution and characteristics of DCX-expressing cells in surgical and postmortem samples from 40 adult and paediatric patients, with epilepsy and with or without hippocampal sclerosis (HS), compared to post mortem controls. The hippocampus (pes and body), parahippocampal gyrus, amygdala, temporal pole and temporal cortex were examined with DCX immunohistochemistry using four commercially-available DCX antibodies, labelled cells were quantified in different regions of interest as well as their co-expression with cell type specific markers (CD68, Iba1, GFAP, GFAP2, nestin, SOX2, CD34, OLIG2, PDGFRß, NeuN) and cell cycle marker (MCM2). Histological findings were compared with clinical data, as well as gene expression data obtained from the temporal cortex of 83 temporal lobe epilepsy cases with HS. DCX immunohistochemistry identified immature $\left(\mathrm{Nestin}^{-} / \mathrm{NeuN}^{-}\right)$neurons in layer II of the temporal neocortex in patients with and without epilepsy. Their number declined significantly with age but was not associated with the presence of hippocampal sclerosis, seizure semiology or memory dysfunction. DCX ${ }^{+}$cells were prominent in the paralaminar nuclei and periamygdalar cortex and these declined with age but were not significantly associated with epilepsy history. DCX expressing cells with ramified processes were prominent in all regions, particularly in the hippocampal subgranular zone, where significantly increased numbers were observed in epilepsy samples compared to controls. DCX ramified cells co-expressed Iba1, CD68 and PDGFR 3 , and less frequently MCM2, OLIG2 and SOX2, but no co-localization was observed with CD34, nestin or GFAP/GFAP d. Gene expression data from neocortical samples in patients with TLE and HS supported ongoing DCX expression in adults. We conclude that DCX identifies a range of morphological cell types in temporal lobe epilepsy, including immature populations, glial and microglial cell types. Their clinical relevance and biological function requires further study but we show some evidence for alteration with age and in epilepsy.
\end{abstract}

Keywords: Doublecortin, Temporal lobe epilepsy, Hippocampus, Memory, Microglia

\section{Introduction}

Doublecortin (DCX) is a microtubule-associated protein critical for normal neuronal migration during development. It has been widely used as a reliable marker to study post-mitotic, immature neurons in the adult mammalian brain $[11,14,33,37]$ as well as responses of these cell types to brain insults $[9,25,51]$. There is anatomically

\footnotetext{
* Correspondence: M.Thom@ucl.ac.uk

'Department of Clinical and Experimental Epilepsy, UCL Institute of Neurology, Queen Square, London WCN1BG, UK

${ }^{2}$ Department of Neuropathology, National Hospital for Neurology and Neurosurgery, UCL Institute of Neurology, Queen Square, London WC1N $3 \mathrm{BG}, \mathrm{UK}$

Full list of author information is available at the end of the article
}

restricted expression in the normal mature mammalian brain, with $\mathrm{DCX}^{+}$multipolar and 'tangled' neurons reported in cortical layer II, mainly in the temporal lobe, in a variety of species $[36,49]$ and in the peri-amydgala association cortex and amygdala [52]. The physiological function of persisting $\mathrm{DCX}^{+}$neurons is unknown: roles in olfactory processing and memory have been postulated [6]. $\mathrm{DCX}^{+}$neurons remain relatively unexplored in humans and their clinical significance is uncertain. $\mathrm{DCX}^{+}$ populations diminish with age in animals [6] but studies have suggested seizure-enhanced maturation and proliferation of $\mathrm{DCX}^{+}$cell types occurs in temporal lobe epilepsy (TLE) $[9,28,40]$ indicative of their underlying plasticity

(c) The Author(s). 2018 Open Access This article is distributed under the terms of the Creative Commons Attribution 4.0 International License (http://creativecommons.org/licenses/by/4.0/), which permits unrestricted use, distribution, and 
and responsiveness. In addition, reports have noted DCX expression in non-neuronal cell types, including in relation to cortical pathology and brain injury and repair $[25,46]$.

The aim of this study was to further explore the morphology, phenotype, distribution and density of $\mathrm{DCX}^{+}$cells in TLE. We included surgical samples from a wide age range both with and without hippocampal sclerosis (HS), the commonest pathology in TLE [4]. We compared this to findings in post-mortem (PM) samples from patients with epilepsy and HS and non-epilepsy controls to explore any differences in the morphology and number of $\mathrm{DCX}^{+}$cells between these groups. In addition we compared the neuropathological findings to available gene-expression data from a parallel study of the temporal lobe cortex from a large series of TLE patients. Neuropathology findings were also correlated with clinical epilepsy history, including type of seizures, aura and any memory dysfunction, to explore pathophysiological roles of these cell types.

\section{Methods}

\section{Case selection}

Fifty-two cases were included in the histological study (Table 1). Adult temporal lobe epilepsy (TLE) cases from patients undergoing elective surgery for the treatment of refractory epilepsy $(n=19)$ were selected from the databases of the Epilepsy Society Brain and Tissue Bank at UCL Institute of Neurology and pediatric TLE surgical cases $(n=5)$ were obtained from Great Ormond Street Hospital NHS Trust. Adult post mortem (PM) tissue from patients with $(n=16)$ or without $(n=12)$ epilepsy during life (healthy controls) was obtained from the Epilepsy Society and MRC sudden death brain banks respectively; none of these patients had undergone neurosurgical treatments during life. The study has ethical approval and all cases were consented for use in research (Ethics committee approval NRES17/SC/0573). In 18/24 surgical cases and $8 / 16$ of the epilepsy PM cases, hippocampal sclerosis (HS) ILAE type 1 [5] was present. None of these cases had additional temporal lobe sclerosis/cortical dysplasia [43] or other lesion.

Tissue was examined from six regions of the temporal lobe in the majority of adult surgical cases, including: (i) temporal neocortex (superior temporal gyrus to fusiform gyrus at $1 \mathrm{~cm}$ rostral to temporal pole) (Fig. 1a), (ii) temporal pole, (iii) mid-hippocampus body, (iii) pes hippocampus, (iv) parahippocampal gyrus (PHG) and (v) amygdala. As a standard anterior temporal lobectomy procedure was performed and a routine tissue handling and processing protocol was followed, the regions selected were anatomically comparable between cases. In surgical cases, the amygdala tissue was typically fragmented which limited identification of all subnuclei. In PM cases, coronal sections of the mid hippocampal body, adjacent temporal cortex and/or sections through the entire mid to caudal amygdala, including the paralaminar nuclei, were examined (Fig. 2a, Additional file 1: Table S1 for details).

\section{Immunohistochemistry}

Immunochemistry for DCX was carried out on $5 \mu \mathrm{m}$ thick formalin-fixed, paraffin-embedded sections. We trialed four DCX commercially-available antibodies on selected

Table 1 Clinical and pathology details of cases and control groups (Further detail of each case is available in Additional file 1: Table S1)

\begin{tabular}{|c|c|c|c|c|c|c|}
\hline Group & Tissue type & NUMBER & $\begin{array}{l}\text { Predominant pattern } \\
\text { of HS in body }\end{array}$ & $\begin{array}{l}\text { Age (at surgery or death); } \\
\text { mean (range, years) }\end{array}$ & Gender & Regions examined/study \\
\hline $\begin{array}{l}\text { Adult epilepsy TLE/HS } \\
\text { (S1-13) }\end{array}$ & Surgical Fixed & 13 & ILAE Type 1 HS & $41.3(22-54)$ & 7F: $6 \mathrm{M}$ & $\begin{array}{l}\text { HB,PES,PHG,TPole, TLobe, } \\
\text { Amyg / qlHC }\end{array}$ \\
\hline $\begin{array}{l}\text { Paediatric epilepsy TLE/HS } \\
\text { (S1-5) }\end{array}$ & Surgical Fixed & 5 & ILAE type $1 \mathrm{HS}$ only & $12.2(8-15)$ & $2 \mathrm{~F}: 3 \mathrm{M}$ & HB, TLobe / q IHC \\
\hline $\begin{array}{l}\text { Adult epilepsy TLE/NO } \\
\text { HS (S19-24) }\end{array}$ & Surgical Fixed & 6 & $\mathrm{NOHS}$ & $28.6(24-35)$ & $2 \mathrm{~F}: 4 \mathrm{M}$ & $\begin{array}{l}\text { HB,PES,PHG,TPole, TLobe, } \\
\text { Amyg / q IHC }\end{array}$ \\
\hline Adult epilepsy (EPM1-16) & Post Mortem & 16 & $\begin{array}{l}\text { ILAE type } 1 \mathrm{HS} \text { in } 8 \\
\text { CASES }\end{array}$ & $48.7(18-75)$ & 8F: $8 \mathrm{M}$ & $\begin{array}{l}\text { HB, PHG, Amyg, Temporal } \\
\text { Cortex (Both hemispheres } \\
\text { included in } 4 \text { cases) / q IHC }\end{array}$ \\
\hline $\begin{array}{l}\text { Adult non-epilepsy } \\
\text { controls (C1-12) }\end{array}$ & Post mortem & 12 & No HS & $56.4(28-85)$ & 5F: $7 \mathrm{M}$ & $\begin{array}{l}\text { HB, PHG, Amyg, Temporal } \\
\text { Cortex / q IHC }\end{array}$ \\
\hline Adult epilepsy TLE/HS & Fresh & $\begin{array}{l}83 \\
77^{\mathrm{a}}\end{array}$ & $\begin{array}{l}\text { All HS (16 with TLS) } \\
\text { All HS (15 with TLS) }\end{array}$ & $\begin{array}{l}36.3(16-63) \\
35.6(16-57)\end{array}$ & $\begin{array}{l}45 \mathrm{~F}-38 \mathrm{M} \\
39 \mathrm{~F}-38 \mathrm{M}\end{array}$ & $\begin{array}{l}\text { Middle temporal gyrus } \\
\text { (cortex) / RNA }\end{array}$ \\
\hline $\begin{array}{l}\text { Adult non-epilepsy } \\
\text { controls }\end{array}$ & Fresh & $\begin{array}{l}73^{\mathrm{b}} \\
59^{\mathrm{a}}\end{array}$ & $\begin{array}{l}\text { No HS } \\
\text { No HS }\end{array}$ & $\begin{array}{l}50.8(20-79) \\
28.8(13-55)\end{array}$ & $\begin{array}{l}14 \mathrm{~F}-53 \mathrm{~F} \\
30 \mathrm{~F}-29 \mathrm{M}\end{array}$ & $\begin{array}{l}\text { Middle temporal gyrus } \\
\text { (cortex)/ RNA } \\
\text { A1C, inferior and superior TC }\end{array}$ \\
\hline
\end{tabular}

S surgical epilepsy case, EPM adult epilepsy post-mortem, C Post-mortem control, HB Hippocampal body, PES pes hippocampus, PHG parahippocampal gyrus, TPole temporal pole, TLobe temporal lobe, TLS temporal lobe sclerosis, Amyg amygdala, HS hippocampal sclerosis, qIHC qualitative and quantitative immunohistochemistry, RNAseq RNA sequencing and expression analysis, ILAE International League against epilepsy, TLE temporal lobe epilepsy.

a Only samples from adolescence and young and middle adulthood period. Controls from Kang et al.

${ }^{b}$ Samples obtained from the MRC brain bank, Edinburgh. A1C = Primary auditory cortex 


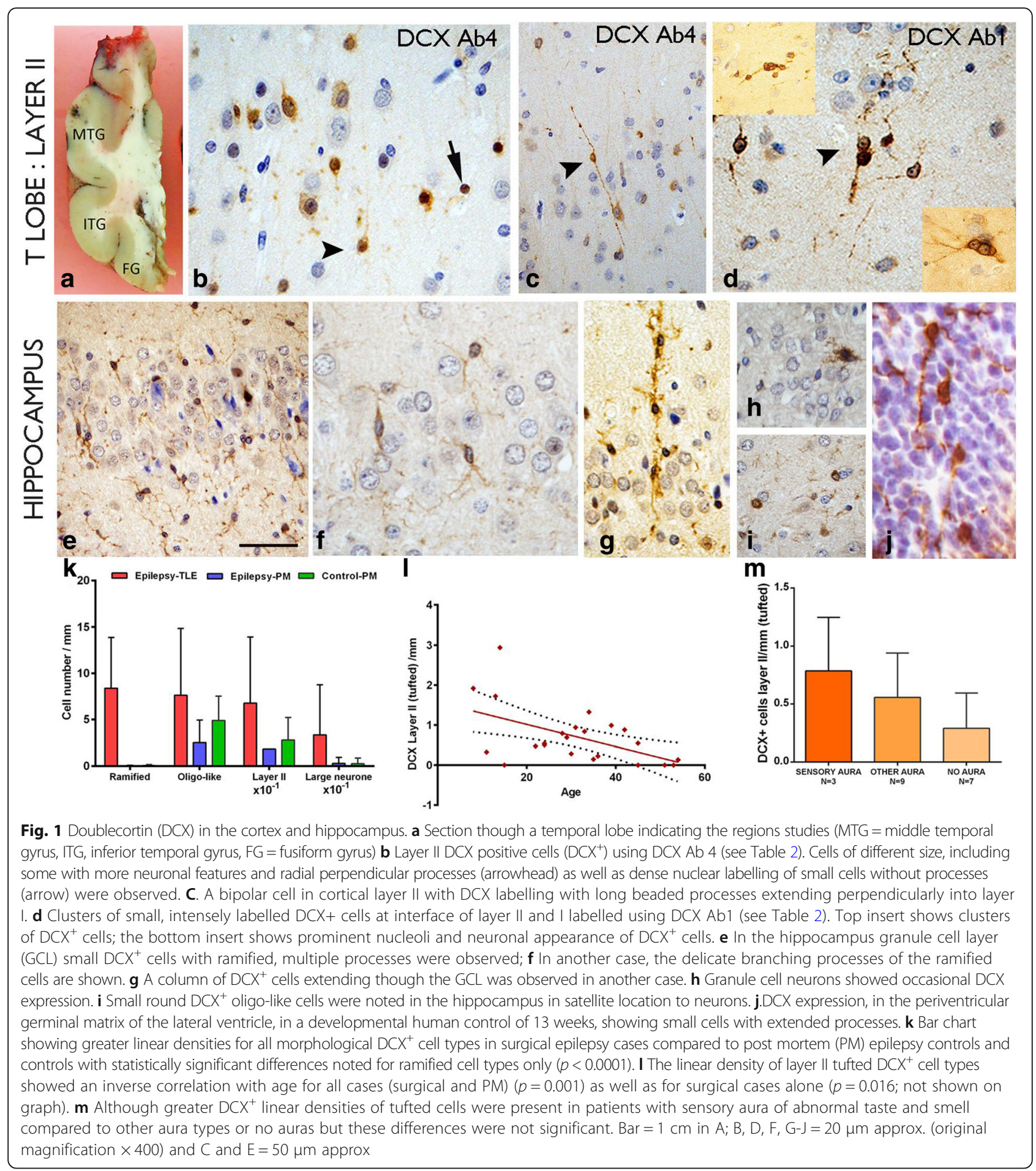

surgical and PM cases. All four antibodies were previously validated in publications on human tissues $[9,28,34,40,46]$ (Table 2; DCX Ab1 to 4). All DCX antibodies showed immunopositive labelling, but DCX Ab1 (clone 4604, Cell signaling, Boston, USA) labelled a greater diversity of cell types, and more intense labelling was observed in both surgical and PM human brain tissues. Consequently, DCX Ab1 was used across all cases for the descriptive and quantitative analysis. Double label immunofluorescent studies were performed on all anatomical regions of five selected surgical cases (Additional file 1: Table S1); combinations included DCX Ab1 with different DCX antibodies, and DCX Ab1 with astroglial (GFAP, GFAP-ð), microglial (Iba1, HLA-DR, CD68), mature neuronal (NeuN), immature/stem cells 


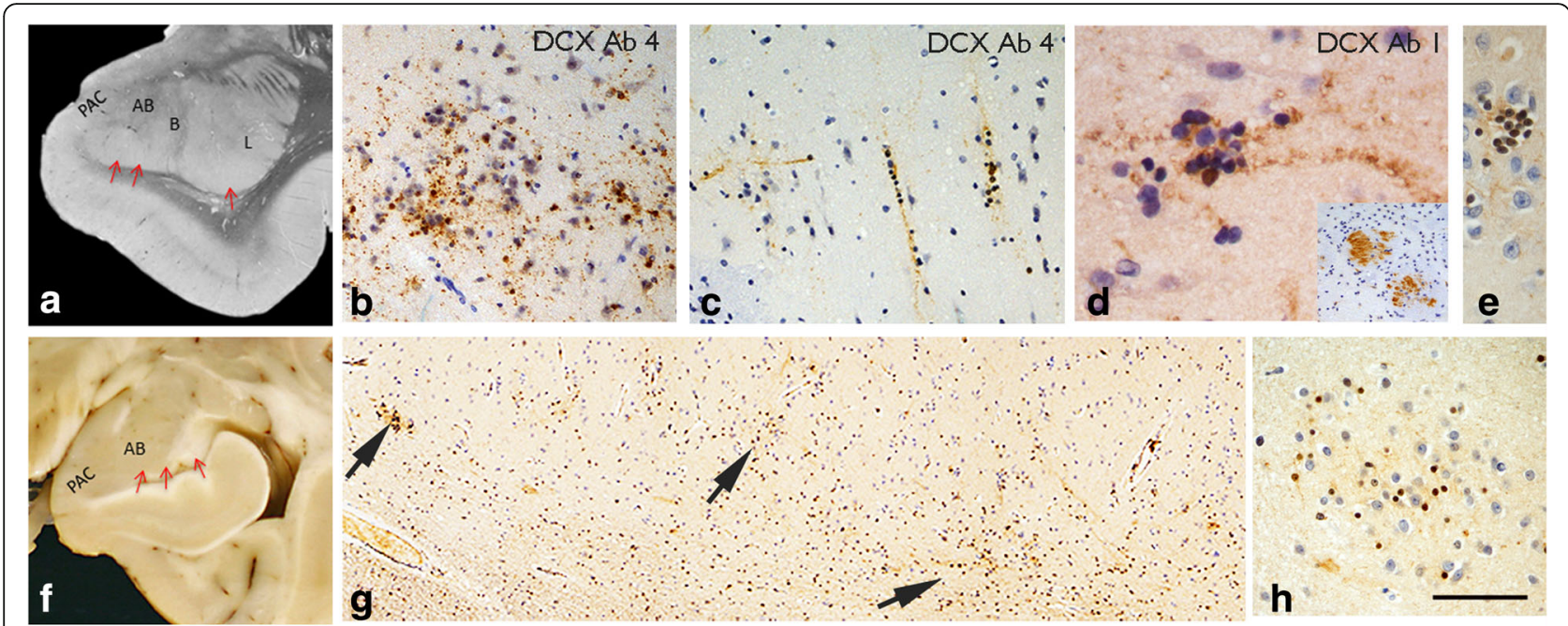

Fig. 2 Amygdala and DCX expression. a Coronal level though caudal amygdala in a post mortem case indicating the location of the paralaminar nucleus with red arrows. PAC = peri-amygdala cortex, $A B=$ accessory basal, $B=$ basal and $L=$ lateral nuclei. $\mathbf{b}$ DCX positive cells clusters and beaded fibres in the PAC of a surgical patient with TLE/HS; c In a further case, columns of DCX+ cells were seen in the PAC as well as horizontal processes. d Further surgical TLE/HS case with DCX Ab1 (see Table 2) with clusters of small immature cells with beaded processes and some with nuclear labelling (inset: shows coarser DCX+ bundles traversing the amygdala in a surgical case). e Clusters of small densely labelled immature DCX+ cells and processes in the amygdala in post mortem samples of paralaminar nucleus. $\mathbf{f}$ Post mortem caudal amygdala indicating the location of the paralaminar nucleus above the ventricle. $\mathbf{g}$ The paralaminar nucleus shown at low magnification in DCX labelled section, with nests of positive cells and clusters of processes indicated (arrows) running along the border. $\mathbf{h}$ At higher magnification these clusters correspond to small DCX ${ }^{+}$cells intermingled with DCX

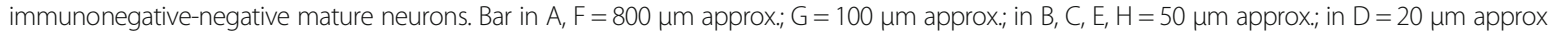

(nestin, CD34, SOX2), oligodendroglia (OLIG2), NG2-cells and pericytes (PDGFR $\beta)[11,16]$ and cell cycle markers (MCM2). Details of the immunostaining protocols are included in Table 2 and the Additional file 2.

\section{Quantitative and qualitative analysis}

DCX-immuno-labelled cells $\left(\mathrm{DCX}^{+}\right)$at the boundaries of cortical layer I/II in the temporal lobe of all cases were quantified using Image pro plus (Media Cybernetics, Cambridge, UK). Sequential images were captured at $x$ 40 using a Leica DBMR microscope along the entire length of layer I and II from the gyrus to the sulcus of the most inferior-mesial gyrus (fusiform gyrus (FG) or inferior temporal gyrus (ITG))(Fig. 1a). $\mathrm{DCX}^{+}$cells of different morphologies were counted and expressed as cells per mm of gyrus length. $\mathrm{DCX}^{+}$cell types in other anatomical regions were semi-quantified as: (0) absent, $(+)$ rare/occasional, $(++)$ moderate numbers, $(+++)$ many cells. In PM cases where the entire coronal cross-section of the paralaminar nucleus was present, the presence of $\mathrm{DCX}^{+}$cells was evaluated as: (0) absent, $(+)$single cluster, $(++)$ 2-3 clusters, and $(+++)>4$ clusters. In the adjacent peri-amygdala cortex (PAC; Fig. 2a) DCX in the superficial cortex was assessed as: $(+)$ occasional single $\mathrm{DCX}^{+}$cell, $(++)$ several single cells or one cluster, $(+++) 2-3$ clusters, $(++++)>4$ clusters.

Qualitative examinations of double-labelled sections were carried out with a Zeiss Axio Imager Z2, and confocal laser scanning microscope (LSM-Meta 710, Zeiss, Göttingen, Germany). The software, Zen 2012 blue lite version (Zeiss, Göttingen, Germany), was used to view z-stacks of confocal images, and to compose three-dimensional orthogonal projections.

\section{DCX mRNA analysis}

Histology data was compared to DCX mRNA expression analyses from 83 surgical TLE cases (Table 1); in 16 of these cases there was evidence of temporal neocortical sclerosis (layer II/III neuronal loss and gliosis) in addition to hippocampal sclerosis [43]. TLE samples were obtained from the UCL Epilepsy Society Brain and tissue bank and compared to 73 PM non-epilepsy control tissues samples from the MRC Sudden Death Brain and Tissue Bank (Table 1). This data formed part of a separate study (Matarin et al., in preparation). We also compared this data to pre-existing expression array data; specifically DCX mRNA expression in ten different brain regions of non-epilepsy control cases including occipital, temporal, frontal, hippocampus, putamen, thalamus, substantia nigra, white matter, medulla and cerebellum as well as different life periods from embryonic to late adulthood [21].

For temporal lobe cases (patients and controls), RNA was isolated from the middle temporal gyrus (MTG) cortex and samples were randomly placed and hybridized to Affymetrix Exon 1.0 ST arrays as previously described [22]. Control tissue from other brain regions and different 
Table 2 Immunohistochemistry panel

\begin{tabular}{|c|c|c|c|}
\hline Antibody & Product code, Supplier & Dilution (method) & Target Epitope \\
\hline$\frac{\mathrm{DCX}}{\mathrm{Ab1}}$ & 4606, Cell Signaling Tech. Boston, US. *Used in [28] & 1:250 (IHC, IF) & Amino acid sequence $40-70$ and $350-410$ of human DCX \\
\hline $\begin{array}{l}\mathrm{DCX} \\
\mathrm{Ab} 2\end{array}$ & $\begin{array}{l}\text { AB18723, Abcam, Cambridge, UK. } \\
\text { *Used in }[34,40]\end{array}$ & $1: 4000(\mathrm{IF})$ & AA 300 to the C-terminus of synthetic human DCX \\
\hline $\begin{array}{l}\text { DCX } \\
\text { Ab3 }\end{array}$ & $\begin{array}{l}\text { SC-8066, Santa Cruz Biotech. Heidelberg, Germany. } \\
\text { *Used in }[11,24,27]\end{array}$ & $1: 400(\mathrm{IF})$ & C-terminus $365-402$ of human DCX \\
\hline $\begin{array}{l}\mathrm{DCX} \\
\mathrm{Ab} 4\end{array}$ & $\begin{array}{l}\text { AB2253, EMD Millipore, Watford UK. } \\
\text { *Used in }[45,46]\end{array}$ & 1:1000 (IHC, IF) & C-terminus 350-365 \\
\hline Nestin & AB22035, Abcam, Cambridge, UK. & $1: 1000(\mathrm{IHC}, \mathrm{IF})$ & $\begin{array}{l}150 \text { aa recombinant fragment from human nestin } \\
\text { conjugated to GST }\end{array}$ \\
\hline Nestin & AB105389, Abcam, Cambridge, UK. & 1:100 (IF) & $\begin{array}{l}\text { Synthetic peptide corresponding to the } C \text { terminus of } \\
\text { Human Nestin. }\end{array}$ \\
\hline Sox 2 & AB5603, EMD Millipore, Hertfordshire, UK. & 1:400 (IF) & $\begin{array}{l}\text { KLH-conjugated linear peptide corresponding to a } \\
\text { C-terminal region sequence of human Sox } 2\end{array}$ \\
\hline GFAP-Ә & AB93251, Abcam, Cambridge, UK, & 1:4000 (IF) & $\begin{array}{l}\text { Synthetic peptide conjugated to KLH derived from within } \\
\text { residues } 350 \text { to the C-terminus of Mouse GFAP } \partial\end{array}$ \\
\hline GFAP & Z0334, DAKO, Cambridgeshire, UK. & 1:1500 (IF) & GFAP \\
\hline NeuN & MAB377, EMD Millipore, Hertfordshire, UK. & 1:100 (IF) & Purified neuronal nuclei \\
\hline Iba1 & 019-19,741, WAKO, Osaka, Japan. & $1: 6000(\mathrm{IF})$ & Synthetic peptide corresponding to C-terminus of Ibal \\
\hline CD68 & AB783, Abcam, Cambridge, UK. & $1: 50(\mathrm{IF})$ & Macrophages, microglia \\
\hline CD34 & IR632, DAKO, Cambridgeshire, UK. & $1: 25(\mathrm{IF})$ & Endothelial cells \\
\hline Olig 2 & AB9610, EMD Millipore Hertfordshire, UK & $1: 200(I F)$ & Recombinant mouse Olig-2 \\
\hline PDGFR-beta & AB32570, Abcam, Cambridge, UK. & 1:1000 (IF) & $\begin{array}{l}\text { Synthetic peptide within Human PDGF Receptor beta aa } \\
1050 \text { to the C-terminus }\end{array}$ \\
\hline MCM2 & 610,700, BD biosciences, Oxford, UK. & 1:900 (IF) & Human BM28 aа. $725-888$ \\
\hline
\end{tabular}

For all antibodies, sections were pre-treated in sodium citrate solution ( $\mathrm{pH} 6.0$ ) microwaved at $800 \mathrm{~W}$ for twelve minutes. All primary antibodies were incubated overnight at $4{ }^{\circ} \mathrm{C}$, except for anti-lba1, CD68 and GFAP which were incubated for an hour at room temperature, and anti-GFAP $\partial$ which was incubated for $48 \mathrm{~h}$ at $4{ }^{\circ} \mathrm{C}$. *Previous studies using DCX in human tissue studies.

Abbreviations: IHC immunohistochemistry, IF immunofluorescence

life periods were also originally analysed with Affymetrix Exon 1.0 ST arrays [21] and data files were downloaded from the NCBI Gene Expression Omnibus (accession GSE25219 and GSE46706). Quality control analyses included background correction, quantile normalization, $\log 2$ transformation and median polishing probe-set summarization. The effects of several methodological and biological covariates were tested for significance and was included in the linear regression or MANOVA models when significant. All gene expression data was analyzed with Affymetrix Power Tools software package and Partek Genomics Suite (Partek Incorporated, St. Louis, MO, USA) and R software.

\section{Clinical data}

The age of onset of seizures, age at surgery, seizure types, laterality and outcomes at two years following surgery were obtained from the clinical records of epilepsy patients (Table 1 and Additional file 1: Table S1). Pre-operative memory function tests were carried out as part of the routine clinical assessment as previously described [44] and detailed in Additional file 2: Methods. Data on memory function was available in 15 adult surgical patients (Additional file 1: Table S1). Statistical analysis was carried out between pathology and clinical groups using non-parametric tests (including Kruskal-Wallis with post-hoc corrections and Spearman correlation) SPSS (IBM, California, version 22); $p$ values of $\leq 0.05$ were regarded as significant.

\section{Results \\ Qualitative findings \\ $D C X^{+}$neuronal cell types}

Neuronal-appearing unipolar (Fig. 1b), bipolar (Fig. 1c) and multipolar DCX ${ }^{+}$cells (Fig. 1d) were identified mainly at the interface between layer I and II of the temporal cortex as single cells or more rarely in clusters or rows (Fig. 1d); they were observed in 18 of the 22 surgical cases studied and henceforth are collectively referred to as 'layer II DCX ${ }^{+}$cells'. The processes of multipolar tufted cells extended mainly perpendicularly to the cortical surface, projecting into layer I, where rarer horizontallyorientated $\mathrm{DCX}^{+}$cells and processes could be observed. In all cases, layer II DCX+ cells intermingled with other 
small, intensely labelled $\mathrm{DCX}^{+}$cells without processes in layer II (Fig. 1b) and occasionally with larger $\mathrm{DCX}^{+}$cells with more overt neuronal morphology (Fig. 1b). Layer II $\mathrm{DCX}^{+}$cells appeared more frequent along the ITG and FG compared to MTG in surgical TLE cases. Layer II $\mathrm{DCX}^{+}$cells were also observed in the temporal pole of over half of the cases studied, but less frequently in the resected parahippocampal gyrus (PHG) and PM TLE and control cases. Rare large $\mathrm{DCX}^{+}$neuronal cells were noted in the granule cell layer of the hippocampus in surgical cases (Fig. 1h).

\section{$D C X^{+}$glial cell types}

Ramified $\mathrm{DCX}^{+}$cells with multiple, branching processes were visualized mainly with the DCX antibody DCX Ab1 (Fig. 1e). Ramified $\mathrm{DCX}^{+}$cells were present in all regions of all TLE cases, with and without HS, and all PM cases and noted in the gray and white matter. In the hippocampus, ramified $\mathrm{DCX}^{+}$cells were particularly prominent in the hilus and subgranular zone of the dentate gyrus, extending through the granule cell layer. Occasional clusters or columns of $\mathrm{DCX}^{+}$cells were seen (Fig. 1g) and proximity to CA1 pyramidal neurones. There were also present in the pes hippocampus and PHG in all cortical layers and white matter. Ramified cells were morphologically reminiscent of microglia and $\mathrm{NG}^{+}$cells as well as immature migrating neurons in the developing fetal brain in the periventricular zone (Fig. 1j). Occasional cells were also noted alongside vessels. In addition, a population of small round $\mathrm{DCX}^{+}$ oligo-like cells, without cytoplasmic processes, were scattered in white matter and cortex, visualized with all DCX antibodies; similar cells were often seen in a satellite position adjacent to neurons (Fig. 1i), particularly in deep cortical layers, as previously reported [40].

\section{$D C X^{+}$cells in amygdala}

Surgical cases The peri-amygdala cortex (PAC) and paralaminar/periventricular nuclei could be anatomically identified in surgical cases, but were incompletely represented. All DCX antibodies labelled clusters of small $\mathrm{DCX}^{+}$cells, mainly in the superficial cortex of the PAC (Fig. 2b-d). These $\mathrm{DCX}^{+}$cells were sometimes arranged in horizontal or vertical columns, with beaded linear processes (Fig. 2c). Fragments of amygdalar nuclei with a ventricular border (paralaminar nuclei) showed aggregates of small, intensely-labelled $\mathrm{DCX}^{+}$cells and fibres intermingled with DCX-negative, mature neurons. Coarse fibre tracts and bundles of $\mathrm{DCX}^{+}$processes were also occasionally noted in the amygdala of all surgical cases (Fig. 2d, inset). In addition, ramified $\mathrm{DCX}^{+}$cells with cytoplasmic labelling, as observed in other regions, were widespread. PM cases: Variable labelling of small $\mathrm{DCX}^{+}$cell aggregates in the paralaminar nucleus of the amygdala was noted, particularly along the ventricle wall in the caudal amygdala (Fig. 2f, g). In these regions, clusters of small immature $\mathrm{DCX}^{+}$nuclei were intermingled with larger and intermediate-sized DCX-negative neurones. (Fig. 2h). Some $\mathrm{DCX}^{+}$cells were associated with fine beaded bipolar processes Fig. 2e). In the PAC, scattered small immature $\mathrm{DCX}^{+}$cells with processes were noted, occasionally in clusters, mainly at the interface between layer I and II in either horizontal or perpendicular arrangements, as in the surgical cases.

\section{Double labelling studies and comparison of different $D C X$ antibody labelling}

DCX antibodies DCX Ab1 showed the most extensive labelling of cells and processes in different regions but co-localization was confirmed in a proportion of small cells with the three other different DCX antibodies (Table 2, Fig. 3a). Temporal neocortex: In layer II of the temporal lobe, $\mathrm{DCX}^{+}$tufted cells showed only rare co-localisation with mature neuronal marker NeuN (Fig. 3b, c). There was no cellular co-expression of DCX with mature glial marker GFAP, immature stem cell markers nestin or GFAPd, which both showed labelling of the sub-pial band of astrocytes (Fig. 3e). There were a few $\mathrm{DCX}^{+} / \mathrm{Sox}^{+}$cells noted. There were no $\mathrm{CD} 34^{+}$neuroglial cells in any of the surgical epilepsy cases. A minor proportion of small oligo-like DCX+ cells in the white matter co-expressed OLIG2 (Fig. 3d); in contrast, MCM2/ $\mathrm{DCX}^{+}$cells were not observed (Fig. 3d inset). There was extensive co-localisation between ramified $\mathrm{DCX}^{+}$ cells and Iba1, CD68 and, to a lesser extent, PDGFR $\beta$. Hippocampus body and pes: Very rare $\mathrm{DCX}^{+} / \mathrm{NeuN}^{+}$ cells were observed in the granule cell layer (Fig. 3f). We did not observe any co-expression between GFAP, GFAPd and nestin with DCX and these markers highlighted distinct cell populations in all regions (Fig. 3g). There was, however, prominent co-localization of ramified, multipolar DCX+ cells with Iba1 (Fig. 3h) and CD68 (Fig. 3i), particularly in the granule cell layer region. In addition, co-expression of DCX with PDGFR $\beta$ was evident in some small branching cells as well as MCM2 (Fig. 3j). Occasional double-labelling of small oligo-like cells with DCX and OLIG2 as well as SOX2 was noted in hippocampal regions but not with CD34. Amygdala: Although $\mathrm{DCX}^{+}$and nestin-expressing cells were observed in similar anatomical regions, particularly in the paralaminar nucleus, they highlighted distinct cell populations and processes (Fig. 3k, l). Multipolar, ramified $\mathrm{DCX}^{+}$cells showed co-expression with Iba1 (Fig. 3m) and occasionally with PDGFR $\beta$ (Fig. 3n), but only in a proportion of cells. Cellular co-expression of DCX with NeuN, CD34, GFAP or MCM2 (fig. 3o) was not observed in the amygdala of the cases examined and there was rare co-expression of DCX with OLIG2 or SOX2. 


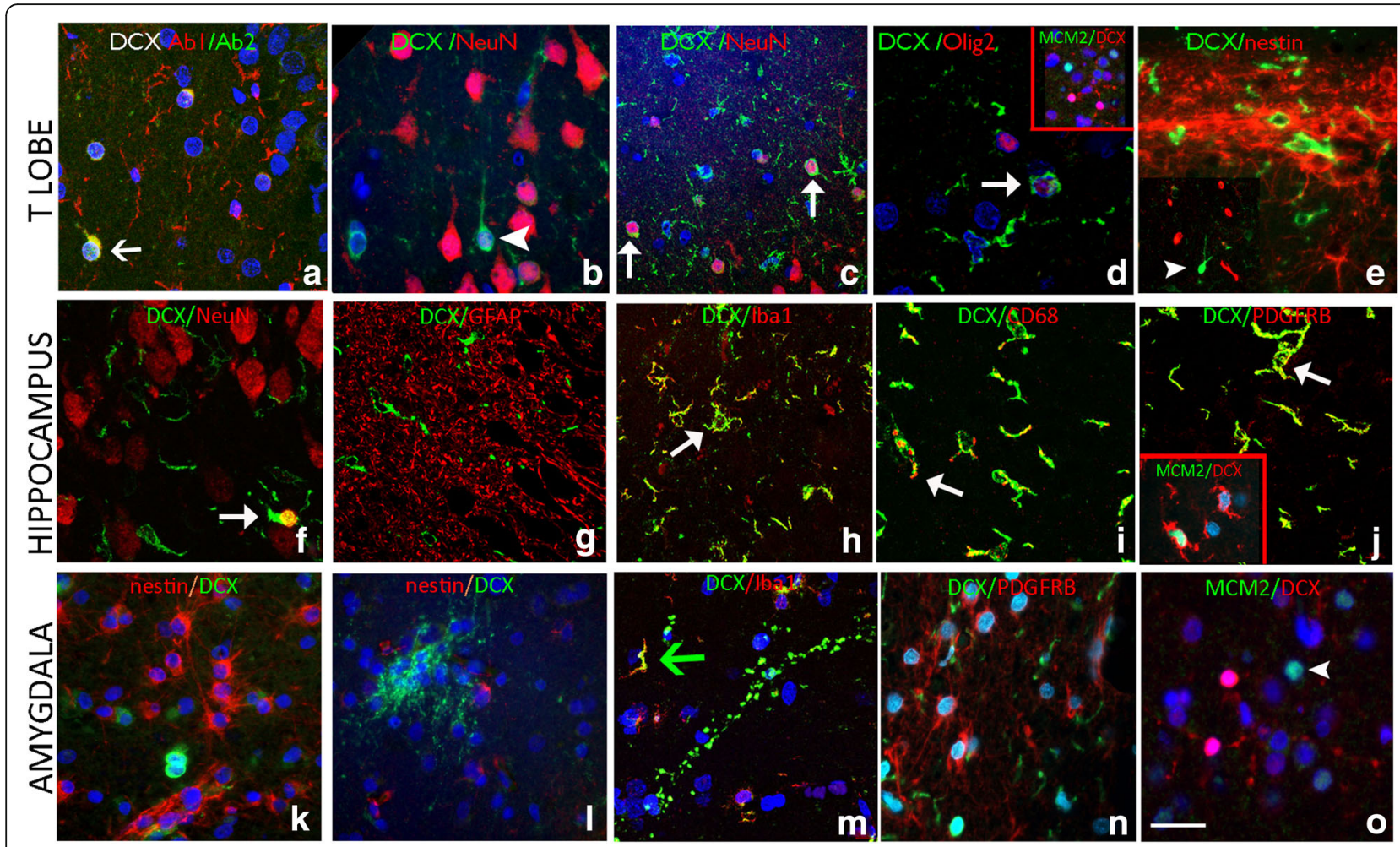

Fig. 3 Characterizing DCX positive cells in the temporal cortex, hippocampus and amygdala of surgical patients with epilepsy, and comparison of commercial antibodies. In all panels, the arrowheads indicate single labelled cells, while arrows point to double labelled cells. Confocal images are merged projections of 5 to 7 images acquired in a z-stack. a. The immunoreactivity of two different commercially-available anti-Dcx antibodies. Both DCX Ab2 AB18723 (Abcam, Cambridgeshire, UK) and DCX Ab 1 \#4606 (Cell Signaling Technology, Inc. MA, USA) labelled small cells in the hippocampal granule cell layer (GCL) of a patient with epilepsy and HS Type 1 (arrow) (Table 2). DCX Ab1 labelled more cells overall than DCX Ab2. DCX+ positive cells in the remaining figures were labelled using DCX Ab1. Temporal Cortex Layer I/ll: $\mathbf{b}$. NeuN expression was not frequently observed in small DCX+ cells located in layer II of the temporal lobe cortex (arrowhead). c. In another case, DCX/NeuN positive cells were more frequently observed in the superficial temporal cortex than in the temporal pole (arrows). $\mathbf{d}$. DCX positive cells expressing Olig2 in the nucleus (arrow) were noted in layer 1 of an epilepsy case (arrow), but MCM2/DCX+ cells were not observed (inset). e. Nestin+ glial fibres were observed in the subpial layer and layer I and II, but did not co-localise with DCX expression. Hippocampus: $\mathbf{f}$. In general there were rare DCX/NeuN colocalised cells in the dentate gyrus; in this image there is a rare co-localised cell (arrow). g. GFAP showed dense labelling of astroglial process in hippocampal regions but no co-localisation with DCX was noted. $\mathbf{h}$. Labelling with Iba1 highlighted mature microglial cell types, with ramified processes, particularly in the subgranular zone as shown, and many co-expressed DCX (arrow); $\mathbf{i}$ Co-labelled CD68/DCX+ cells were also observed (arrow). j. PDGFRß was expressed in multipolar cells in the hippocampus and temporal lobe in addition to pericytes; focal co-labelling with DCX was noted in some cells (arrow); Inset show a DCX+ ramified cell expressing MCM2 in the nucleus. Amygdala. $\mathbf{k}$. Distinct populations or clusters of nestin+ or DCX+ cells in the amygdala periventricular nuclei; I. In another area, nests of DCX+ processes were also distinct from nestin-expressing cells. $\mathbf{m}$. In the amygdala, although DCX+ processes were largely lba1 negative, Iba1/DCX+ ramified DCX+ cells were observed (arrow). $\mathbf{n}$. PDGFRß and DCX in the amygdala showing distinct populations of small cells. $\mathbf{0}$. DCX in the amygdala were mainly MCM2 negative. Bar is equivalent to $20 \mu \mathrm{m}$. Individual channels for immunofluorescence images are shown in Additional file 4: Figure S2

\section{Quantitative analysis}

Based on the above findings our hypothesis was that quantitative analysis would confirm greater densities in the number of $\mathrm{DCX}^{+}$cells in epilepsy than control groups. In the temporal lobe we confirmed higher linear densities for all morphological $\mathrm{DCX}^{+}$cell types in surgical epilepsy cases compared to PM epilepsy cases and non-epilepsy controls (Fig. 1k) with statistically significant differences noted for ramified $\mathrm{DCX}^{+}$cell populations $(p<0.0001)$. We also investigated their relationship with patient age and cortical region. The linear density of layer II cells compared to other $\mathrm{DCX}^{+}$cell types showed an inverse correlation with age for all cases (surgical and PM) $(p=$ $0.001)$ (Fig. 1l) as well as for surgical cases alone $(p=0.016)$ and for age of seizure onset $(p=0.035)$. There were significantly higher linear densities of tufted $\mathrm{DCX}^{+}$cells in the FG compared to the ITG $(p=0.004)$ but not for other $\mathrm{DCX}^{+}$cells types. We also hypothesized if there was a relationship between $\mathrm{DCX}^{+}$linear densities and the presence of HS but did not confirm this. Similarly, we considered if DCX cell densities related to clinical parameters; there was no significant difference in $\mathrm{DCX}^{+}$cells in relation to seizure types (focal or generalized seizures), history of aura (Fig. $1 \mathrm{~m}$ ) or if patients were seizure free (or not) two years 
following surgery. We noted an association for increased ramified $\mathrm{DCX}^{+}$in cortical layer II in patients with severe verbal pre-operative memory deficit (Additional file 3: Figure $\mathrm{S} 1 ; p=0.027$ ). In other regions (hippocampus, pes hippocampus, PHG and temporal pole and amygdala), semi-quantitative analysis of $\mathrm{DCX}^{+}$ramified and small cell types in surgical cases did not show any significant differences between cases with HS or without HS, relationship to age at surgery, age of seizure onset, seizure types or outcome at 2 years. In PM cases, there were no significant differences in DCX populations in amygdala and PAC between epilepsy controls and controls; there was a negative correlation between $\mathrm{DCX}^{+}$cells in the PAC and age over all PM cases $(p=0.04)$.

\section{mRNA expression}

From published data [21] $D C X$ mRNA was expressed in all brain regions tested and exhibited temporal and regional significant differential expression (False Discovery Rate 5\%). There was higher DCX mRNA expression in temporal, frontal and occipital regions and lower in cerebellum. DCX expression in the temporal cortex was higher in periods before and early birth (embryonic, fetal and early infancy) than in periods following the early infancy (late infancy, childhood, adolescence and adulthood) (Fig. 4a). We observed no significant differences in $D C X$ expression in the temporal cortex between left and right hemispheres in controls [21] or TLE patients (adolescence and young and middle adulthood periods) (Fig. 4b). We did not find significant differences between patients with and without temporal lobe sclerosis and neither between patients with epilepsy and the 2 PM control groups (Fig. 4c) (For all $p$ values $>0.05$ and fold change $<1.2$ ).

\section{Discussion}

DCX is currently widely used as developmental marker for post-mitotic, immature neurons in the brain and for persistent neurogenesis in adulthood [14, 37]. Our study highlights the varied morphologies of $\mathrm{DCX}^{+}$cells in adult TLE with ongoing expression supported by a parallel gene expression study. Tangled $\mathrm{DCX}^{+}$cells in layer II of the temporal cortex did not express nestin, NeuN or MCM2, declined in numbers with age and did not significantly associate with clinical seizure semiology, memory dysfunction or the presence of HS. Amygdala DCX+ immature neuronal populations were primarily located in the paralaminar nucleus, but their number and morphology were not different between cases and controls. We also identified a subset of ramified and small cells with DCX antibodies, representing a range of glial cell types and supporting non-neuronal DCX expression; these were increased in number in the neocortex in epilepsy, associated with memory impairment and may represent reactive populations.

\section{Temporal cortical $\mathrm{DCX}^{+}$cells in epilepsy}

The presence of persistent, immature, $\mathrm{DCX}^{+}$neocortical cells in layer II, primarily in the temporal lobe and piriform cortex, has been recognized in a range of adult mammalian species since 2001 (reviewed in [6]). They are less studied in humans and their precise physiological function remains elusive. They have been variable termed 'tangled and tufted' cells or 'semilunar/transitional' neurons, co-express PSA-NCAM or other immature neuronal markers but reported to be mainly negative with mature neuronal marker NeuN. Although the number of $\mathrm{DCX}^{+}$ cortical cells decline with age, they are considered to endow the cortex with enhanced synaptic plasticity [23] and roles in olfactory learning and memory have been postulated [6]. In mammals they are not considered to be newly generated in adulthood, but to arise during development from migrating cells of the lateral cortical stream [2]. A persistent temporal lobe migratory stream has also been recently described in adult mammals, extending from the temporal pole of the lateral ventricle to the piriform cortex and amygdala [14] and we have also recently reported evidence for vestiges of a similar migratory stream in the human adult mesial temporal lobe [27]. In TLE an increased plexus of PSA-NCAM-positive neurons was reported in layer II of the entorhinal cortex [30] and increased $\mathrm{DCX}^{+}$cells were noted in the temporal neocortex in epilepsy compared to controls with evidence for some maturation with NeuN expression, yet maintaining a persistent immature phenotype (98\% co-expressing PSA-NCAM and 82\% Tuj1) [28]. Similar tangled DCX cells in layer II were also prominent in young patients with FCD type Ia [40].

In the current series, layer II DCX+ temporal neocortical cells showed infrequent NeuN expression, in keeping with some previous studies $[15,40]$; the additional lack of expression of the stem cell marker nestin could support their intermediate differentiation between progenitor cells and mature neurons [27]. We confirmed their anatomical distribution, with increased density in more mesial temporal neocortex, as suggested in previous reports $[6,28]$. They were not prominent in the parahippocampal gyrus cortex however and we also observed a significant decline in the number of tangled cells with age. In our recent study of TLE/HS patients aged over 50 years with early Alzheimer-like pathology in temporal lobe resections, we reported a lack of tau accumulation in layer II DCX+ cells, suggesting their resistance to age-related neurodegeneration [42], as also supported by experimental models [52]. We have shown in this study that the number of tangled neurons is not increased in epilepsy patients compared to controls, nor is the number related to clinical olfactory/ sensory auras, memory dysfunction the presence of hippocampal sclerosis or post-surgical outcome. In a parallel gene expression study from patients with TLE/HS there 


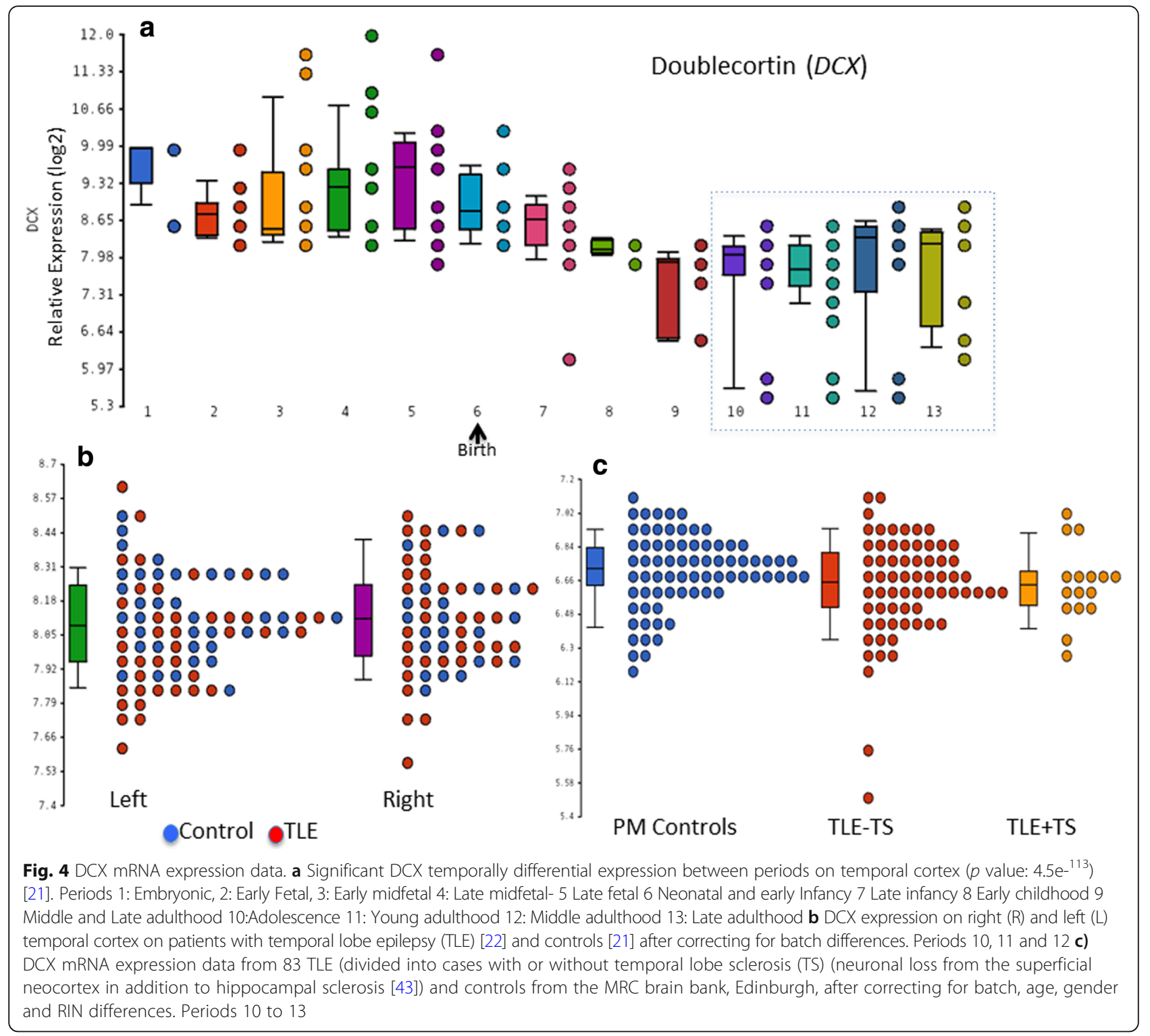

were no significant differences in patients with additional temporal lobe superficial cortical neuronal loss and gliosis (also called temporal lobe sclerosis) [43] from those with normal/preserved neocortex. These findings could suggest that layer II DCX+ cell types are unlikely to be clinical or pathologically relevant to functional and acquired pathologies in temporal lobe epilepsy.

\section{Amygdala and $\mathrm{DCX}^{+}$populations}

The amygdala can initiate seizures in TLE and volume changes, including enlargement are recognized in TLE in addition to gliosis [3]. During development, migrating $\mathrm{DCX}+$ cells in the lateral cortical stream give rise to neuronal and glial populations in the amygdala [2]; persisting DCX+ cells in adulthood have been reported in the primate amygdala and PAC, forming chains of cells, a proportion of which co-express NeuN, their number declining with age [52]. Similar cell types were also confirmed in the human amygdala [29], in particular the paralaminar nucleus of the amygdala, where abundant rests of immature DCX+ neurons were shown in one study [10]. The paralaminar nucleus, which sits along the ventricle wall, is composed of nodules of small primitive appearing cells, and is interconnected with other amygdala nuclei receiving high serotonergic input. Its precise functions are uncertain [10]. In the current study, $\mathrm{DCX}^{+}$immature cells, primarily in the paralaminar nucleus and PAC, were confirmed to exist in the amygdala, in both surgical tissue as well as PM cases. Diminished populations were associated with increasing age but the cells did not show atypical morphology or altered numbers in epilepsy or associate with the presence 
of hippocampal sclerosis. Nevertheless, application of $\mathrm{DCX}^{+}$may be helpful in clinical practice to enable their anatomical identification and avoid over-interpretation as small malformations or hamartias, described in surgical resections in TLE [17].

\section{DCX - A reliable marker of neurogenesis in the mature human brain?}

There is increasing awareness of DCX expression in non-neuronal cells types. DCX-expressing astroglial cells have been noted in adult post mortem tissues in patients with epilepsy and controls [46], in balloon cells in FCD IIB and multipolar astroglial like cells in temporal lobe sclerosis [40]. $\mathrm{DCX}^{+}$stellate cells have been reported in the vicinity of acute infarcts with co-expression of astroglial lineage markers (GFAP, S100) rather than microglial or mature neuronal markers as NeuN [25]. In another study however, $\mathrm{DCX}^{+}$'rod' cells in the infant hippocampal subgranular zone region, that morphologically resembled microglia, lacked CD68 and HLADR expression and were argued to represent neural progenitor cell types [34]. In adult mammals, $\mathrm{DCX}^{+}$cells are reported to be enriched in the subgranular zone of the hippocampus, and are described as 'ramified', although exhibiting more overt neuronal morphology with apical dendrites [14, 36]. Experimental tracing studies of $\mathrm{DCX}^{+}$cell fate during temporal lobe development show that $95 \%$ give rise to TBR1-positive pyramidal neurons but a small proportion differentiate to GFAP astrocytes (3.4\%) and a further population of small bipolar cells with sparsely branching processes are of uncertain lineage (1.7\%) [2]. Single cell transcriptomics of isolated $\mathrm{DCX}^{+}$populations has also provided evidence of cell subsets enriched for divergent pathways, including astrocytic and myelinating oligodendroglial fates [15]. Identification of DCX expression in oligodendroglial precursor cells (OPC) was proposed to reflect cell migration rather than neuronal differentiation [7] and DCX expression is also speculated to have a role in glioblastoma infiltration [1].

Our current study adds further support to DCX expression in non-neuronal cell types. We noted frequent ramified, multipolar $\mathrm{DCX}^{+}$cells and oligo-like cells without processes in many regions, including the SGZ, and these were significantly increased in surgical TLE compared to controls. These were observed mainly with one DCX antibody although overlap of expression was noted in a proportion of small cells with other commercial DCX antibodies, suggesting different sensitivities. Although $\mathrm{DCX}^{+}$ramified cells in the dentate gyrus resembled cells in the developing human sub-ventricular zone, they lacked the typical unipolar or bipolar morphology [36]. Furthermore, we confirmed that a proportion of ramified $\mathrm{DCX}^{+}$cells co-expressed microglial markers, as well as PDGFR $\beta$, supporting non-neuronal lineages. Significantly more ramified $\mathrm{DCX}^{+}$cells were noted in surgical epilepsy cases in the temporal cortex compared to controls. However there were no differences between epilepsy cases with or without hippocampal sclerosis. These different observations suggest enhanced DCX expression in reactive glial cells types in epilepsy could be independent of underlying pathology.

The observation of DCX in microglia was an unexpected finding. Microglial cells are dynamic, motile cells which show changes in morphology in response to brain activity and injury, with increasingly recognized diverse and complex roles [8, 32] including neurodevelopment as well as epilepsy [13]. Understanding of these cells has advanced with proteomic and transcriptomic analysis of isolated microglia, aiming to identify specific proteins more abundantly expressed, as candidate lineage and activation markers [12, 38, 48, 53] (see https://omictools.com/gliaopen-access-database-tool). Although proteomics and gene expression studies have suggested that DCX is not expressed in microglia at significant levels [18-20, 38, 50, 53], differential gene expression studies do show DCX is dependent on their activation state. For example, one study using laser single cell capture and gene expression of microglial cell types of different morphology showed that DCX was highly enriched in activated amoeboid microglia and confirmed by immunohistochemistry and PCR of a murine microglial cell line [35]. Recent studies have also highlighted expression of putative immature neuronal markers in reactive cell types, including microglia in human slice cultures [47].

Intriguingly we also noted PDGFR $\beta^{+}$co-expression in some of the ramified $\mathrm{DCX}^{+}$cells in TLE tissues; DCX expression has been previously shown in pericytes [53]. Although PDGFR $\beta^{+}$is widely recognized as a CNS pericyte marker [41] it is also expressed in OPC/NG2 parenchymal glial cell types, which are reactive to seizures $[16,26,31,39]$. We also noted occasional $\mathrm{DCX}^{+}$small cells to co-express OLIG2 in keeping with reported low DCX expression in OPC lineages $[7,53]$. In our parallel gene expression study from TLE cortex, DCX expression was confirmed in adult temporal cortex and, although expression was not significantly increased in TLE compared to controls, more detailed single cell analysis is warranted to further investigate differential cellular expression in epilepsy. Our findings therefore support ongoing DCX expression in adults; expression in non-neuronal cells, particularly in adults undergoing surgery for refractory epilepsy, may suggest aberrant upregulation under pathological conditions, including seizures.

\section{Study limitations}

There are several limitations to the study. The ages in the epilepsy and control groups for the histology were not precisely matched as in the mRNA study and although ramified $\mathrm{DCX}^{+}$cell densities did not show a relationship 
with age, we cannot exclude that this may have had an effect. The PM cases with epilepsy and HS did not all have syndromic TLE and limited memory tests were available. The gene expression data on MTG was obtained on homogenized cortex from all cases rather than micro dissected cortical layers or cells and was not carried out on the ITG or FG where greater numbers of $\mathrm{DCX}^{+}$cells are observed. We did not have complete representation of the FG in the surgical specimens, compared to the PM cases in the analysis of Layer II $\mathrm{DCX}^{+}$cells and in the amygdala surgical specimens were fragmentation which limits analysis of the entire nucleus.

\section{Conclusions}

DCX identifies a range of morphological cell types in temporal lobe epilepsy, including immature populations in the superficial cortex and amygdala that decline with age but may not be specifically relevant to the epilepsy or local pathology. We observed $\mathrm{DCX}^{+}$reactive glial cell types, including microglial lineages with some evidence for increased numbers in epilepsy tissue. This suggests that DCX not only is expressed in residual immature neuronal cell types, but may have a role in brain responses to seizure injury.

\section{Additional files}

Additional file 1: Table S1. Detail of each case used in the study including clinical and psychometric data and the type of study carried out (DOCX $29 \mathrm{~kb}$ )

Additional file 2: Supplementary Methods (DOCX $18 \mathrm{~kb}$ )

Additional file 3: Figure S1. Bar graphs of the relationship between pre-operative memory function and DCX+ cells in the superficial temporal lobe. A. There was an association between severe memory deficit and increased ramified type DCX+ cells $(p=0.027)$. However the number of patients in this series is small and requires validation with a larger cohort. B. There was no association between the number of tufted DCX+ neuronal cells in layer II of the temporal cortex and pre-operative memory function. (JPG $181 \mathrm{~kb})$

Additional file 4: Figure S2. Split channels for DCX double labelling as indicated in temporal lobe, hippocampus and amygdala for images shown in Fig. 3. (TIF 15727 kb)

\section{Abbreviations}

DCX: Doublecortin; FG: Fusiform gyrus; HS: Hippocampal sclerosis; ILAE: International league against epilepsy; ITG: Inferior temporal gyrus; MTG: Middle temporal gyrus; OPC: Oligodendroglial precursor cells; PAC: Perimagydala cortex; PHG: Parahippocampal gyrus; PM: Post mortem; TLE: Temporal lobe epilepsy

\section{Acknowledgements}

We are grateful to the MRC sudden death brain bank in Edinburgh for the provision of control cases, to the Human Developmental Biology Resource for paediatric and fetal brain specimens and to Simon Paine and Tom Jacques for the provision of cases from Great Ormond Street Hospital.

\section{Funding}

This work is supported by a grant from the MRC MR/J01270X/1. MM is supported by Marie Curie International Re-integration Grant (FP7-PEOPLE-2009-RG grant No 256545) and Epilepsy Research UK (F1206). JL is currently supported by EPITARGET. This work was undertaken at UCLH/UCL, which received a proportion of funding from the Department of Health's NIHR Biomedical Research Centres funding scheme. The UCL Epilepsy Brain and Tissue Bank is supported by the Katy Baggott Foundation through the Epilepsy Society.

\section{Availability of data and materials}

The sequencing datasets generated and or analysed during the current study are not publicly available at the present time as they are part of an ongoing study and publication in preparation but will then become available on reasonable request.

\section{Authors' contributions}

$J$ and MT prepared the manuscript and figures and carried out all the data analysis. JL carried out the double labelling studies. CR carried out the single labelling studies. MM carried out all the gene expression data and analysis. AM, AM, SS and PT provided all the clinical data. All authors have been involved in final manuscript approval.

\section{Ethics approval and consent to participate}

The study has ethical approval and all cases were consented for use in research (Ethics committee approval: National research ethics committee: NRES17/SC/0573).

\section{Competing interests}

All co-authors have no personal, professional or financial relationships that could potentially be construed as a conflict of interest.

\section{Publisher's Note}

Springer Nature remains neutral with regard to jurisdictional claims in published maps and institutional affiliations.

\section{Author details}

'Department of Clinical and Experimental Epilepsy, UCL Institute of Neurology, Queen Square, London WCN1BG, UK. ${ }^{2}$ Department of Neuropathology, National Hospital for Neurology and Neurosurgery, UCL Institute of Neurology, Queen Square, London WC1N 3BG, UK. ${ }^{3}$ Department of Neurology, National Hospital for Neurology and Neurosurgery, London, UK. ${ }^{4}$ Department of Neuropsychology, National Hospital for Neurology and Neurosurgery, London, UK. ${ }^{5}$ Department of Neurosurgery, National Hospital for Neurology and Neurosurgery, London, UK. ${ }^{6}$ Chalfont Centre for Epilepsy, Chesham Lane, Chalfont St Peter, Buckinghamshire SL9 ORJ, UK. 'Department of Biomedical Sciences, University of Westminster, W1W6UW, London, UK.

Received: 21 May 2018 Accepted: 3 July 2018

Published online: 13 July 2018

References

1. Ayanlaja AA, Xiong Y, Gao Y, Ji G, Tang C, Abdikani Abdullah Z, Gao D (2017) Distinct features of Doublecortin as a marker of neuronal migration and its implications in Cancer cell mobility. Front Mol Neurosci 10:199. https://doi.org/10.3389/fnmol.2017.00199

2. Bai J, Ramos RL, Paramasivam M, Siddiqi F, Ackman JB, LoTurco JJ (2008) The role of DCX and LIS1 in migration through the lateral cortical stream of developing forebrain. Dev Neurosci 30:144-156. https://doi.org/10.1159/ 000109859

3. Beh SMJ, Cook MJ, D'Souza WJ (2016) Isolated amygdala enlargement in temporal lobe epilepsy: a systematic review. Epilepsy \& behavior: E\&B 60:33-41. https://doi.org/10.1016/j.yebeh.2016.04.015

4. Blumcke I, Spreafico R, Haaker G, Coras R, Kobow K, Bien CG, Pfafflin M, Elger C, Widman G, Schramm J et al (2017) Histopathological findings in brain tissue obtained during epilepsy surgery. N. Engl. J. Med. 377:1648-1656. https:/doi.org/10.1056/NEJMoa1703784

5. Blumcke I, Thom M, Aronica E, Armstrong DD, Bartolomei F, Bernasconi A, Bernasconi N, Bien CG, Cendes F, Coras R et al (2013) International consensus classification of hippocampal sclerosis in temporal lobe epilepsy: a Task Force report from the ILAE Commission on Diagnostic Methods. Epilepsia 54:1315-1329. https:/doi.org/10.1111/epi.12220

6. Bonfanti L, Nacher J (2012) New scenarios for neuronal structural plasticity in non-neurogenic brain parenchyma: the case of cortical layer II immature neurons. Prog Neurobiol 98:1-15. https://doi.org/10.1016/j. pneurobio.2012.05.002 
7. Boulanger JJ, Messier C (2017) Doublecortin in oligodendrocyte precursor cells in the adult mouse brain. Front Neurosci 11:143. https://doi.org/10. 3389/fnins.2017.00143

8. Cartier N, Lewis CA, Zhang R, Rossi FM (2014) The role of microglia in human disease: therapeutic tool or target? Acta Neuropathol 128:363-380. https://doi.org/10.1007/s00401-014-1330-y

9. D'Alessio L, Konopka H, Lopez EM, Seoane E, Consalvo D, Oddo S, Kochen S, Lopez-Costa JJ (2010) Doublecortin (DCX) immunoreactivity in hippocampus of chronic refractory temporal lobe epilepsy patients with hippocampal sclerosis. Seizure 19:567-572. https://doi.org/10.1016/j.seizure.2010.09.004

10. deCampo DM, Fudge JL (2012) Where and what is the paralaminar nucleus? A review on a unique and frequently overlooked area of the primate amygdala. Neurosci Biobehav Rev 36:520-535. https://doi.org/10.1016/j. neubiorev.2011.08.007

11. Dennis CV, Suh LS, Rodriguez ML, Kril JJ, Sutherland GT (2016) Human adult neurogenesis across the ages: an immunohistochemical study. Neuropathol Appl Neurobiol 42:621-638. https://doi.org/10.1111/nan.12337

12. Dong X, You Y, Wu JQ (2016) Building an RNA sequencing transcriptome of the central nervous system. The Neuroscientist: a review journal bringing neurobiology, neurology and psychiatry 22:579-592. https://doi.org/10.1177/ 1073858415610541

13. Eyo UB, Murugan $M$, Wu $\sqcup$ (2017) Microglia-neuron communication in epilepsy. Glia 65:5-18. https://doi.org/10.1002/glia.23006

14. Fasemore TM, Patzke N, Kaswera-Kyamakya C, Gilissen E, Manger PR, Ihunwo AO (2018) The distribution of Ki-67 and Doublecortin-Immunopositive cells in the brains of three Strepsirrhine Primates: Galago demidoff, Perodicticus potto, and Lemur catta. Neuroscience 372:46-57. https://doi.org/10.1016/j. neuroscience.2017.12.037

15. Gao $Y$, Wang F, Eisinger BE, Kelnhofer $L E$, Jobe EM, Zhao X (2016) Integrative single-cell transcriptomics reveals molecular networks defining neuronal maturation during postnatal neurogenesis. Cereb Cortex. https://doi.org/10. 1093/cercor/bhw040

16. Garbelli R, de Bock F, Medici V, Rousset MC, Villani F, Boussadia B, ArangoLievano M, Jeanneteau F, Daneman R, al BF (2015) PDGFRbeta(+) cells in human and experimental neuro-vascular dysplasia and seizures. Neuroscience 306:18-27. https://doi.org/10.1016/..neuroscience.2015.07.090

17. Gawelek KL, Gales JM, Prayson RA (2018) Hamartia in hippocampal sclerosisassociated mesial temporal lobe epilepsy. Ann Diagn Pathol 32:63-66. https://doi.org/10.1016/j.anndiagpath.2017.08.004

18. Han D, Moon S, Kim Y, Kim J, Jin J, Kim Y (2013) In-depth proteomic analysis of mouse microglia using a combination of FASP and StageTip-based, high pH, reversed-phase fractionation. Proteomics 13:2984-2988. https:/doi.org/ 10.1002/pmic.201300091

19. Hickman SE, Kingery ND, Ohsumi TK, Borowsky ML, Wang LC, Means TK, El Khoury J (2013) The microglial sensome revealed by direct RNA sequencing. Nat Neurosci 16:1896-1905. https://doi.org/10.1038/nn.3554

20. Ji P, Schachtschneider KM, Schook LB, Walker FR, Johnson RW (2016) Peripheral viral infection induced microglial sensome genes and enhanced microglial cell activity in the hippocampus of neonatal piglets. Brain Behav Immun 54:243-251. https://doi.org/10.1016/j.bbi.2016.02.010

21. Kang HJ, Kawasawa Yl, Cheng F, Zhu Y, Xu X, Li M, Sousa AM, Pletikos M, Meyer KA, al SG (2011) Spatio-temporal transcriptome of the human brain. Nature 478:483-489. https://doi.org/10.1038/nature10523

22. Kasperaviciute D, Catarino CB, Matarin M, Leu C, Novy J, Tostevin A, Leal B, Hessel EV, Hallmann K, al HMS (2013) Epilepsy, hippocampal sclerosis and febrile seizures linked by common genetic variation around SCN1A. Brain: a journal of neurology 136:3140-3150. https://doi.org/10.1093/brain/awt233

23. Klempin F, Kronenberg G, Cheung G, Kettenmann H, Kempermann G (2011) Properties of doublecortin-(DCX)-expressing cells in the piriform cortex compared to the neurogenic dentate gyrus of adult mice. PLoS One 6:e25760. https://doi.org/10.1371/journal.pone.0025760

24. Knoth R, Singec I, Ditter M, Pantazis G, Capetian P, Meyer RP, Horvat V, Volk B, Kempermann G (2010) Murine features of neurogenesis in the human hippocampus across the lifespan from 0 to 100 years. PLoS One 5:e8809. https://doi.org/10.1371/journal.pone.0008809

25. Kunze A, Achilles A, Keiner S, Witte OW, Redecker C (2015) Two distinct populations of doublecortin-positive cells in the perilesional zone of cortical infarcts. BMC Neurosci 16:20. https://doi.org/10.1186/s12868-015-0160-8

26. Kyyriainen J, Ekolle Ndode-Ekane X, Pitkanen A (2017) Dynamics of PDGFRbeta expression in different cell types after brain injury. Glia 65:322-341. https://doi. org/10.1002/glia.23094
27. Liu J, Reeves C, Jacques T, McEvoy A, Miserocchi A, Thompson P, Sisodiya S, Thom M (2018) Nestin-expressing cell types in the temporal lobe and hippocampus: morphology, differentiation, and proliferative capacity. Glia 66:62-77. https://doi.org/10.1002/glia.23211

28. Liu YW, Curtis MA, Gibbons HM, Mee EW, Bergin PS, Teoh HH, Connor B, Dragunow M, Faull RL (2008) Doublecortin expression in the normal and epileptic adult human brain. Eur J Neurosci 28:2254-2265. https://doi.org/ 10.1111/j.1460-9568.2008.06518.x

29. Marti-Mengual U, Varea E, Crespo C, Blasco-Ibanez JM, Nacher J (2013) Cells expressing markers of immature neurons in the amygdala of adult humans. Eur J Neurosci 37:10-22. https://doi.org/10.1111/ejn.12016

30. Mikkonen M, Soininen $H$, Kalvianen R, Tapiola T, Ylinen A, Vapalahti M, Paljarvi L, Pitkanen A (1998) Remodeling of neuronal circuitries in human temporal lobe epilepsy: increased expression of highly polysialylated neural cell adhesion molecule in the hippocampus and the entorhinal cortex. Ann Neurol 44:923-934. https://doi.org/10.1002/ana.410440611

31. Milesi S, Boussadia B, Plaud C, Catteau M, Rousset MC, De Bock F, Schaeffer M, Lerner-Natoli M, Rigau V, Marchi N (2014) Redistribution of PDGFRbeta cells and NG2DsRed pericytes at the cerebrovasculature after status epilepticus. Neurobiol Dis 71:151-158. https://doi.org/10.1016/.jnbd.2014.07.010

32. Nayak D, Roth TL, McGavern DB (2014) Microglia development and function. Annu Rev Immunol 32:367-402. https://doi.org/10.1146/annurev-immunol032713-120240

33. Nogueira AB, Sogayar MC, Colquhoun A, Siqueira SA, Marchiori PE, Teixeira MJ (2014) Existence of a potential neurogenic system in the adult human brain. J Transl Med 12:75. https://doi.org/10.1186/1479-5876-12-75

34. Paine SM, Willsher AR, Nicholson SL, Sebire NJ, Jacques TS (2014) Characterization of a population of neural progenitor cells in the infant hippocampus. Neuropathol Appl Neurobiol 40:544-550. https://doi.org/10. 1111/nan.12065

35. Parakalan R, Jiang B, Nimmi B, Janani M, Jayapal M, Lu J, Tay SS, Ling EA, Dheen ST (2012) Transcriptome analysis of amoeboid and ramified microglia isolated from the corpus callosum of rat brain. BMC Neurosci 13:64. https://doi. org/10.1186/1471-2202-13-64

36. Patzke N, LeRoy A, Ngubane NW, Bennett NC, Medger K, Gravett N, Kaswera-Kyamakya C, Gilissen E, Chawana R, Manger PR (2014) The distribution of doublecortin-immunopositive cells in the brains of four afrotherian mammals: the Hottentot golden mole (Amblysomus hottentotus), the rock hyrax (Procavia capensis), the eastern rock sengi (Elephantulus myurus) and the four-toed sengi (Petrodromus tetradactylus). Brain Behav Evol 84:227-241. https:/doi.org/10.1159/000367934

37. Shahsavani M, Pronk RJ, Falk R, Lam M, Moslem M, Linker SB, Salma J, Day K, Schuster J, al ABM (2017) An in vitro model of lissencephaly: expanding the role of DCX during neurogenesis. Mol Psychiatry. https://doi.org/10.1038/ mp.2017.175

38. Sharma K, Schmitt S, Bergner CG, Tyanova S, Kannaiyan N, Manrique-Hoyos N, Kongi K, Cantuti L, Hanisch UK (1819) Philips MAet al (2015) cell typeand brain region-resolved mouse brain proteome. Nat Neurosci 18:-1831. https://doi.org/10.1038/nn.4160

39. Shepherd C, Liu J, Goc J, Martinian L, Jacques TS, Sisodiya SM, Thom M (2013) A quantitative study of white matter hypomyelination and oligodendroglial maturation in focal cortical dysplasia type II. Epilepsia 54:898-908. https://doi.org/ 10.1111/epi.12143

40. Srikandarajah N, Martinian L, Sisodiya SM, Squier W, Blumcke I, Aronica E, Thom M (2009) Doublecortin expression in focal cortical dysplasia in epilepsy. Epilepsia 50:2619-2628. https://doi.org/10.1111/j.1528-1167.2009.02194.x

41. Sweeney MD, Ayyadurai S, Zlokovic BV (2016) Pericytes of the neurovascular unit: key functions and signaling pathways. Nat Neurosci 19:771-783. https://doi.org/10.1038/nn.4288

42. Tai XY, Koepp M, Duncan JS, Fox N, Thompson P, Baxendale S, Liu JY, Reeves C, Michalak Z, Thom M (2016) Hyperphosphorylated tau in patients with refractory epilepsy correlates with cognitive decline: a study of temporal lobe resections. Brain J Neurol 139:2441-2455. https://doi.org/10.1093/brain/ aww187

43. Thom M, Eriksson S, Martinian L, Caboclo LO, McEvoy AW, Duncan JS, Sisodiya SM (2009) Temporal lobe sclerosis associated with hippocampal sclerosis in temporal lobe epilepsy: neuropathological features. J Neuropathol Exp Neurol 68:928-938. https://doi.org/10.1097/NEN.0b013e3181b05d67

44. Thompson PJ, Baxendale SA, McEvoy AW, Duncan JS (2015) Cognitive outcomes of temporal lobe epilepsy surgery in older patients. Seizure 29:41-45. https://doi.org/10.1016/j.seizure.2015.03.017 
45. Verwer RW, Sluiter AA, Balesar RA, Baaijen JC, de Witt Hamer PC, Speijer D, Li Y, Swaab DF (2015) Injury response of resected human brain tissue in vitro. Brain Pathol 25:454-468. https://doi.org/10.1111/bpa.12189

46. Verwer RW, Sluiter AA, Balesar RA, Baayen JC, Noske DP, Dirven CM, Wouda J, van Dam AM, Lucassen PJ, Swaab DF (2007) Mature astrocytes in the adult human neocortex express the early neuronal marker doublecortin. Brain J Neurol 130:3321-3335. https://doi.org/10.1093/brain/awm264

47. Verwer RW, Sluiter AA, Balesar RA, Baayen JC, Speijer D, Idema S, Swaab DF (2016) Altered loyalties of neuronal markers in cultured slices of resected human brain tissue. Brain Pathol 26:523-532. https://doi.org/10.1111/bpa.12330

48. Wes PD, Holtman IR, Boddeke EW, Moller T, Eggen BJ (2016) Next generation transcriptomics and genomics elucidate biological complexity of microglia in health and disease. Glia 64:197-213. https:/doi.org/10.1002/glia.22866

49. Xiong K, Luo DW, Patrylo PR, Luo XG, Struble RG, Clough RW, Yan XX (2008) Doublecortin-expressing cells are present in layer II across the adult Guinea pig cerebral cortex: partial colocalization with mature interneuron markers. Exp Neurol 211:271-282. https://doi.org/10.1016/j.expneurol.2008.02.003

50. Yoo Y, Byun K, Kang T, Bayarsaikhan D, Kim JY, Oh S, Kim YH, Kim SY, Chung Wl, Kim SU et al (2015) Amyloid-beta-activated human microglial cells through ER-resident proteins. J. Proteome Res 14:214-223. https://doi.org/10.1021/ pr500926r

51. Zhang L, Hernandez VS, Estrada FS, Lujan R (2014) Hippocampal CA field neurogenesis after pilocarpine insult: the hippocampal fissure as a neurogenic niche. J Chem Neuroanat 56:45-57. https://doi.org/10.1016/j.jchemneu. 2014.02.002

52. Zhang XM, Cai Y, Chu Y, Chen EY, Feng JC, Luo XG, Xiong K, Struble RG, Clough RW, Patrylo PR et al (2009) Doublecortin-expressing cells persist in the associative Cereb Cortex and amygdala in aged nonhuman Primates. Front Neuroanat 3:17. https://doi.org/10.3389/neuro.05.017.2009

53. Zhang Y, Chen K, Sloan SA, Bennett ML, Scholze AR, O'Keeffe S, Phatnani HP, Guarnieri P, Caneda C, al RN (2014) An RNA-sequencing transcriptome and splicing database of glia, neurons, and vascular cells of the Cereb Cortex. J Neurosci Off J Soc Neurosci 34:11929-11947. https://doi.org/10.1523/ JNEUROSCI.1860-14.2014

\section{Ready to submit your research? Choose BMC and benefit from:}

- fast, convenient online submission

- thorough peer review by experienced researchers in your field

- rapid publication on acceptance

- support for research data, including large and complex data types

- gold Open Access which fosters wider collaboration and increased citations - maximum visibility for your research: over $100 \mathrm{M}$ website views per year

At BMC, research is always in progress.

Learn more biomedcentral.com/submissions 